\title{
Analysis and Research on Local Government Debt Problems in China
}

\author{
Fan Zou \\ College of Management, Jinan University, Guangzhou, China \\ Email: zoufan1213@foxmail.com
}

How to cite this paper: Zou, F. (2019) Analysis and Research on Local Government Debt Problems in China. Modern Economy, 10, 188-197.

https://doi.org/10.4236/me.2019.101013

Received: December 21, 2018

Accepted: January 15, 2019

Published: January 18, 2019

Copyright $\odot 2019$ by author(s) and Scientific Research Publishing Inc. This work is licensed under the Creative Commons Attribution International License (CC BY 4.0).

http://creativecommons.org/licenses/by/4.0/

\begin{abstract}
As China is in the process of urbanization, local governments often assume the responsibility for the construction of most public facilities, and thus have strong investment needs. Under the current trend of large and growing local debts in China, local governments in all regions and at all levels in China have a lot of debt operations and complex debt relationships. The accumulation of local debts leads to the out-of-control of the scale of debts, which seriously affects the normal operation of government agencies and hinders the development of the economy, which is prone to huge financial risks and social conflicts. In order to control the risk of debt, the central government began to adopt a series of policies in 2018 to implement debt limit management for local governments, and the national local government debt limit was 21 trillion yuan. In this context, this paper starts from the status quo and problems of local government debt, accurately analyzes the causes and mechanisms of debt formation, and proposes specific measures and methods to rationally control debt growth and reduce risks, in order to strengthen local government debt management and resolve social conflicts. This article provides guidance advice.
\end{abstract}

\section{Keywords}

Local Government Debt, Debt Risk, Causes and Countermeasures

\section{Introduction}

Since the reform and opening up, China's economy has achieved remarkable developments, and such development is inseparable from the vigorous construction of infrastructure by various local governments. However, in the course of development in recent years, in order to alleviate the financial crisis, the government has adopted an expansionary economic policy to stimulate the devel- 
opment of the economy. Some local governments still have problems of illegality and disguised borrowing, the way of borrowing is increasingly diversified and risks are increasing.

The introduction of the new budget law in 2014 clearly clarified that the only legal way for local governments to borrow is to issue local government bonds. Local governments at all levels have accelerated the establishment of a standardized debt financing mechanism to prevent and resolve financial and financial risks, and achieved phased results. However, in order to obtain a large amount of funds, local governments still borrow heavily through various means, and the debts are getting bigger and bigger. As local governments' debts continue to accumulate, the debt risks they face are gradually increasing, affecting economic and social development, the normal operation of local finances, and may even trigger fiscal and financial risks and social risks.

On March 24, 2018, the Ministry of Finance launched a series of policies, such as the Notice on Doing a Good Job in Local Government Debt Management in 2018, and "preventing the resolution of major risks" as an important task. Guiding and resolving stock debts, curbing implicit debt increments and risks, and improving existing local government debt management policies are of great significance to the current healthy economic development and social harmony and stability.

Local debt is a "double-edged sword". Moderate local government debt can promote local economic development and improve the overall service capacity of the government. However, excessive government borrowing may reduce its enforcement power, induce instability, and directly affect the normal operation of government agencies. Therefore, we must be aware of China's current local debt scale and debt repayment risk, actively formulate policies, rationally control the scale of debt, and ensure the rapid development of local economy and social harmony and stability.

\section{The Status Quo of Local Government Debt Risk in China}

\subsection{The Scale of Debt Is Large and the Pressure for Repayment Is Large}

From the results of the national local government debt audit in 2011, as of the end of 2010, the national local government debt balance was 10.7 trillion yuan. As of December 2013, the National Audit Office released data showing that as of June 2013, all levels of government across the country The debt balance was 30.2 trillion yuan, of which the central government's debt balance was 12.4 trillion yuan, while the local government debt balance was as high as 17.8 trillion yuan, more than the central government debt of about 6 trillion yuan.

The release of China's local government bond issuance and other debt data released by the Ministry of Finance in January 2018 shows that as of the end of 2017, the total national balance of local government debt is basically controlled within the limits approved by the National People's Congress. The balance of 
government debt in China is 29.95. One trillion yuan, of which the central government's national debt balance is 13.48 trillion yuan, and the local government debt balance is 16.47 trillion yuan. This is because in 2013, the National Audit Office carried out local government debt audit work nationwide, publicized the situation of local government debt, and required government departments at all levels to disclose debt information, and local governments paid attention to controlling the scale of debt. Due to the special circumstances of China's vast territory and complex public conditions, local political power is higher than political power, so it still needs large expenditures in developing local economy and stabilizing local security. As a result, China's local government debt still maintains a large base and local debts are repaid. The situation is still grim [1].

\subsection{Local Debt Recessive}

It is unscientific to look at the explicit debt of the government. At the same time, it is necessary to consider implicit debt, so the scale of local debt is very large [2].

Explicit debt refers to the government responsible for establishing a law or contract. When the debt expires, the government has a statutory obligation to pay off the debt, mainly referring to domestic currency bonds issued in the country and foreign currency bond bonds issued abroad. The difference between explicit liability and implicit liability lies in the degree of explanation of the debt clause in the contract and the different binding force of the debt on the enterprise. Explicit liabilities specify the amount of liabilities, the period of repayment, the method of repayment, and the liability for breach of contract in a clear contractual clause. Implicit liabilities have no clear terms of contract detailing the repayment of debt. Explicit liabilities are based on explicit contracts, and the performance of their debts is guaranteed by law. It is the basic guarantee for the transaction behavior between enterprises and customers, and must be repaid. Implicit liability is based on implicit contract, which is a reasonable expectation of customers to completely transfer the ownership of goods, and is an implicit commitment of enterprises to customer expectations. Implicit liability is not a liability in the legal sense, but a result of self-conclusion between the firm and the customer.

Since the real debt data is in the hands of local governments, it is not disclosed. At present, there is no complete, accurate and persuasive statistics on the scale of local debt. However, the scale of local debt has become a consensus, and it is extremely urgent to reduce risks.

The problems existing in the implicit debt of local governments in China mainly include: First, the specific scale is unknown. There is no uniform standard for which debts should be included in the local government implicit debts, and no local authorities have the responsibility to disclose the hidden debts of the local governments to investors or relevant departments. Second, the types of debt are diverse. Local governments have different sources of hidden debts, some purchase services through the government; some pass PPP projects; some 
pass guarantees to enterprises and institutions; some use "Internet finance" to borrow debts. Due to the variety of types, it also increases the difficulty of accurately defining the implicit debt of local governments. Third, it is difficult to judge risks effectively. At present, the information on the size, duration, interest rate, capital investment, and financing channels of local government implicit debts are not open and opaque, which is not conducive to the market to judge its risks. And because a large amount of government funds are invested in public welfare projects such as transportation and water conservancy, the income is low, and the government often maintains the capital turnover by means of "borrowing new and old" and increases the risk factor of local government debt $[3]$.

\subsection{Lack of Effective Risk Management Mechanisms}

In the international community, the financial risk management mechanism generally adopts a quantitative management model. Then, on basis of quantification, according to the overall economic development of the country, a "linear indicator system" is established, and a "warning signal" with visual significance is also used. "Lights to monitor the current debt size". When a debt problem arises, effective measures can be taken to monitor the debt at the first time. However, China's current debt situation is relatively complicated, and there are many kinds of debts, and most of them are still in the form of implicit debt. Even if they have corresponding management measures and systems, they are subject to various objective conditions for local governments. The constraints cannot be perfected like the international community, in order to monitor and warn government debts.

\section{The Cause of Local Government Debt in China}

\subsection{The Local Government's Powers and Financial Resources Do Not Match}

In 1994, the tax-sharing reform redefined the local fiscal revenue, but did not adjust the local expenditure responsibility accordingly. The local government's budget became increasingly heavy, and the regions were even more bitter and uneven. Since the reform of the tax-sharing system, in the important social service areas, such as education, health care, culture and science, local government expenditures accounted for almost $90 \%$ of the total expenditure. The local government's financial and administrative rights are seriously mismatched, resulting in some local finances. Difficulties, have to rely on debt to spend the day.

China's "Legislative Law" defines the watershed between the National People's Congress and the State Council and between the central and local governments in terms of legislative power, but as far as its substance is concerned, it is not as clear as the constitutions of other countries or the special laws on local self-government. A list of laws: what are the central things, what are the localities, and which are shared by the central and local governments. Because of the 
low degree of rule of law, the unequal relationship between the central and local governments has become a normal state in the Chinese fiscal system in the past few decades, and often causes the embarrassing situation of "central hospitality and local paying".

For example, in order to honor the commitment of the country to "open the purchase of surplus grain" to the peasants, the State Council issued the "Decision on Further Deepening the Reform of the Grain Circulation System" in 1998. The second part of the "Decision" "reasonably divides the central and local food rights and responsibilities and comprehensively implements the responsibility system for the food governor" is the content of the division of powers. The main responsibility assigned to the State Council is "macro-control", and the local. The main responsibility of the government is to "make a good job in grain purchases". In other words, the central government gives policy and unified command, and the specific expenditure responsibility is borne by the local finance.

In recent years, the central government has pushed the "shed reform" policy. This policy is also a major source of local explicit and implicit debt growth in recent years, as it improves the living conditions of a large number of urban housing residents. The transformation of a shanty town continued to progress as planned, and the task indicators were decomposed at different levels. Under the dual tasks of repaying old debts and controlling new debts, local governments at all levels generally faced greater pressure on fiscal revenue and expenditure and debt relief.

\subsection{Performance View Manipulation}

For a long time, China has been simply using GDP and its speed to assess the performance of local governments and leading cadres. This mechanism is a kind of "championship" political incentive for local officials. This unreasonable and irregular performance appraisal mechanism has spawned a one-sided view of political achievements of local governments, especially leading cadres. Based on the maximization of their own political interests, local government officials are often keen to complete the tasks that are most likely to reflect their own performance. They are reflected in the large-scale infrastructure construction of "visible and tangible", short-term behavior, great success, and eagerness Cheng, keen on advanced development, over-investment, regardless of the actual project, regardless of the cost of capital, regardless of the consequences to create image projects, resulting in local government debt remains high, the more rolling [4].

\subsection{Unbalanced Financial Transfer Payments}

At present, the state implements a proactive fiscal policy, and when necessary, issues a certain amount of national debt to stimulate economic growth. Treasury bonds are mainly used for investment in infrastructure construction. Due to the long period of infrastructure construction projects, the effect is slow, and the national debt project requires certain local funds. Supporting, some local govern- 
ments have limited financial resources and have to solve them through financing. China has a vast territory and uneven development among regions. Some funds are tilted towards economically backward areas. Some transfer payments are made by special subsidies. The subsidy quotas and standards are not based on strict powers. The funds are not transparently distributed, and the funds are free. Some funds are not available. Reasonable use, due to special ribs, cannot be used in series, the financial resources required by some local governments for the most basic services are difficult to be guaranteed, because the funds between projects cannot be compensated, in addition, the transfer payment system lags, the inter-regional financial allocation is not All of them led to the occurrence of debts from some local governments.

\subsection{Accountability for Illegal and Illegal Financing Is Not in Place}

Many local governments have not implemented the responsibility for territorial management. They even believe that illegal and illegal borrowing on projects and construction is conducive to local development. The accountability of relevant violations and violations is not in place, and the restrictions are softened, resulting in the emergence of illegal and illegal borrowing. The financial regulatory department's system of accountability to financial institutions is still not perfect, and the penalties for relevant violations are not strict.

For example: On September 25, 2018, the National Audit Office issued Announcement No. 48 of 2018, "Tracking Results of the Implementation of Major National Policy Measures in the Second Quarter of 2018". The audit results show that 9 cities, counties (districts) of the six provinces/autonomous regions have formed a local government implicit debt of 8.863 billion yuan by signing a government purchase service agreement. In July and September of 2017, the departments affiliated to Yuhang District and the relevant units signed a government purchase service agreement contract for the renovation of rural houses, road repairs and building demolition, with an agreement amount of 5.278 billion yuan. The agreement stipulated that the purchase of service funds should be included in the budget. As of the end of June 2018, Yuhang District of Hangzhou City formed government implicit debt of RMB 4.007 billion through government procurement services. According to the Financial Affairs [2017] No. 87 document issued by the Ministry of Finance in May 2017, "Notice on Resolutely Stopping the Local Government's Infringement of Financing in the Name of Government Purchase Service", except for the shantytown renovation and the promotion of poverty alleviation in the unified deployment of the Party Central Committee and the State Council. In addition to the government purchase of services involved in the work, the government shall purchase the services strictly in accordance with the scope of the regulations. Document No. 87 emphasizes that "construction of raw materials, fuels, equipment, products, etc., as well as new construction, alteration and expansion of buildings and structures, and related renovation, demolition, repair and other construction projects" shall not be 
taken as government procurement services. Obviously, after the publication of the No. 87 document, the case still included the construction project of "farm house renovation, road repair, i.e. building demolition, etc." into the government purchase service agreement, which obviously did not meet the requirements of Document 87.

\section{Local Government Debt Risk Reform Proposals}

\subsection{To Promote the Process of Legalization of the Relationship between Central and Local Affairs}

The future construction of the legal system dealing with the relationship between the central and local affairs of China will largely determine the progress and difficulty of solving the problem of local government debt. First of all, in the constitution and the law, the concept of "decentralization" between the central and local governments is established to promote a highly transparent central and local game relationship based on legal rules. In this process, the relative independence of local powers should be fully guaranteed, and local expenditure responsibilities should not be arbitrarily increased. At the same time, government powers based on the law should not be arbitrarily deprived.

\subsection{The Rule of Law Reform of the Financial Market Mechanism}

In the process of local government debt financing, due to the existence of a large number of moral hazard problems, the scale of local debt exceeds the necessary limit, so some control mechanism must be introduced. Otherwise, the situation of local government behavior getting out of control will be updated through the legal system [5]. To make the current local government's hidden debts explicit, so that the local government's debt situation can be fully displayed in front of the financial market, and the rational choice of "self-financing" investors in the financial market to determine the possibility of local government financing. At the institutional level, the moral hazard of financial markets is reduced by increasing the transparency of local government debt, and then the market mechanism is used to effectively control the local government's debt-raising behavior.

Let countless investors in the financial market play the role of a constrained person in local government financing behavior, give full play to the unique transparent and efficient characteristics of the market mechanism, and use the real-time changing financial product price signals to "discover" the credit status of local governments, and then The government's future behavior choices create market pressure [6].

\subsection{Strengthen Existing Debt Management}

Excessive stock of existing debt is one of the crux of the problem of local government debt risk in China. To solve the local debt risk problem, we must first consider the existing debt stock and strengthen the management of existing debt. 
At present, local governments in China are facing the pressure of high debt interest rate and short repayment period. After dealing with the accumulation of government debt experience, government bond replacement is a good way to alleviate the local debt stock. Local governments can rationally design debt swaps and local government bonds, and replace the original accumulated debt with conservative bonds with low interest rates and long years, which can effectively alleviate the principal and interest repayment pressure of the debts that are about to expire [7].

Actively and steadily resolve the hidden debts of the stock. Adhere to the principle of non-rescue in the central government, and do "who will hold the children", resolutely dispel the "illusion" that the local government believes that the central government will "pay", and resolutely dispel the "illusion" that financial institutions think the government will bottom out. Establish a market-based, rule-of-law debt default mechanism, and realize creditors and debtors to share risks in a timely manner, and prevent violations from spreading in a timely and effective manner. Adhere to the actual situation, classify prudent disposal, continue to rectify illegal guarantees, correct irregularities in government investment funds, PPP, government purchase services, encourage local governments to legally comply with regulations and increase credit, and prevent stock debt chain break risks.

\subsection{Improve the Local Government Debt Risk Early Warning Mechanism}

In the current information age, local government debt risk prevention efforts can make full use of advanced technologies to improve work effectiveness, such as the use of big data analysis, cloud computing platforms, AI and other high-tech, to launch a comprehensive coverage and networked debt risk assessment system. Under the blessing of information technology, all kinds of information will be comprehensively collected and scientifically analyzed. Relevant management can realize dynamic and real-time monitoring of local government's debt risk, and have a comprehensive understanding of various debt fund trends and specific use status. In addition, technical means can also analyze the historical data of local government debt, and provide a reliable and reliable reference for management decision-making under the precise and personalized evaluation.

\subsection{Improve the Intergovernmental Transfer Payment System and Achieve Equalization of Public Service Capabilities}

The state must continuously increase the intensity of transfer payments to economically underdeveloped areas and meet the most basic needs of government public services. Due to the uneven distribution of financial resources in China, the administrative area is large, some regions have high tax bases, and China's taxation system is relatively uniform. However, due to different regions, fiscal expenditure costs will vary. Some regions have higher expenditure costs, and 
some regions have higher expenditure costs. Relatively low, providing the same level of public services in different regions requires different financial expenditures. In order to achieve equalization of public services, it is necessary to transfer funds to ensure the government's capital needs in areas with relatively low economic development levels or high expenditure costs. The state should increase the payment of provincial transfer funds, promote coordinated economic development among regions, and ensure the efficient operation of grassroots governments [8].

\section{Conclusions and Limitations}

In summary, the current local government debt problem in China has a long history, there are many problems, and the potential risks are enormous. Therefore, the Chinese central government and its subordinate governments are required to grasp the essence of local government debt problems, and based on their own functions, adopt effective measures to gradually resolve the debt problem and further reduce the local government debt risk.

The reasons for the local government debt in China, such as the mismatch between the local government's power and financial resources, the concept of political achievements, and the rule of law and the rule of law reform of the financial market mechanism all take time. It needs to take into account the applicability of the current Chinese fiscal system; it is necessary to carry out a slow experimental trial and error to get a better solution, and the current economic situation of each province adopts a soft landing method to gradually carry out governance. This paper analyzes the problems and suggestions of local government debt from a general direction, and cannot give specific suggestions according to the actual situation of each province. This is also a new research direction for the study of local government debt problems in the provinces.

\section{Conflicts of Interest}

The author declares no conflicts of interest regarding the publication of this paper.

\section{References}

[1] An, Y. and Han, Y. (2018) Research on Local Government Debt Risk in China. Cooperative Economy and Technology, No. 18, 174-176.

[2] Xu, Y.C. (2018) Structural Risk of Local Government Debt in China. Statistical Research, 35, 14-28.

[3] Chen, X.D. (2018) Local Government Debt Risk Analysis and Prevention and Control Recommendations. China International Finance (English and Chinese), No. 5, 203-204.

[4] Lu, H.D. (2018) Analysis of Local Government Debt Problems. China Agricultural Accounting, No. 9, 6-7.

[5] Song, F.J. (2018) Discussion on the Transformation of Local Government Investment and Financing Platform. China's Circulation Economy, No. 3, 70-84. 
[6] Qian, L.Y. (2018) Research on the Status Quo, Risk, Existing Problems and Reform Direction of Local Government Debt. Finance and Accounting, No. 12, 206-206.

[7] Chen, L. (2018) Breaking the "Bottom Illusion" and Actively Solving Local Debt Risks. http://www.ce.cn/xwzx/gnsz/gdxw/201803/24/t20180324_28592056.shtml

[8] Xu, Z.D. (2018) Research on the Sustainability of Provincial Local Government Debt in China. Journal of Dongbei University of Finance and Economics, No. 2, 72-83. 